\title{
Use of silicones in fixed aesthetic rehabilitations: clinical case
}

Uso de silicones em reabilitações estéticas fixas: caso clínico

Uso de siliconas en rehabilitaciones estéticas fijas: reporte de caso

Vandre Mesquita TAUMATURGO ${ }^{1}$

Lícia Camila Rocha LEAL ${ }^{2}$

Evamiris França Landim VASQUES ${ }^{3}$

Maria Daniela Balbino SILVA ${ }^{4}$

Edson Vaz LIMA ${ }^{5}$

Taciana França LANDIM ${ }^{6}$

${ }^{1}$ Mestre em Prótese Dentária UNP-RN, Coordenador de Pós-Graduação em Prótese Dentária POSDOC-PI, 64048-110 Teresina - PI, Brasil

${ }^{2}$ Especialista em Prótese Dentária POSDOC-PI, 64048-110 Teresina - PI, Brasil

${ }^{3} P h D$ em Odontologia UNICSUL-SP 08060-070 São Paulo - SP

${ }^{4}$ Cirurgiã-Dentista, Curso de Graduação em Odontologia do Centro Universitário Doutor Leão Sampaio Juazeiro do Norte - CE, Brasil

${ }^{5}$ Especialista em Prótese Dentária POSDOC-PI, 64048-110 Teresina - PI, Brasil

${ }^{6}$ Graduada em Odontologia pela Universidade Federal do Pernambuco (UFPE), Especialista em Endodontia UFC-CE, Brasil

\begin{abstract}
Molding in a fixed prosthesis is one of the most important stages in rehabilitative treatment, as it is there that attempts are made to reproduce dental preparations and adjoining regions by using appropriate materials and techniques. Among the fixed prosthesis molding materials available on the market, the elastomers stand out, which are polymers where the prey occurs through the increase of the chain and the establishment of cross-links. The objective of the study is to present a clinical case and perform a literature review on the use of condensation silicone and addition to molds in Fixed Prosthesis. In this literature review, a survey of PubMed, Scielo and Lilacs data was performed, using the descriptors: Denture, Partial, Fixed; Dental Impression Materials and Elastomers. It is possible to conclude that in the field of Dentistry, the elastomers, among them the condensation-cured and addition-cured silicones, both provide high precision models and are the most used materials in works with fixed partial dentures. Therefore, it is up to the professional to know the properties and adapt to the best group of chosen materials.
\end{abstract}

Descriptors: Denture, Partial, Fixed; Dental Impression Materials; Elastomers.

\section{Resumo}

A moldagem em prótese fixa é uma das etapas mais importantes do tratamento reabilitador, pois é nela que se tenta reproduzir os preparos dentários e as regiões adjacentes por meio de materiais e técnicas adequadas. Dentre os materiais para moldagem de próteses fixas disponíveis no mercado, destacam-se os elastômeros, que são polímeros onde a presa ocorre por meio do aumento da corrente e do estabelecimento de ligações cruzadas. O objetivo do estudo é apresentar um caso clínico e realizar uma revisão da literatura sobre o uso do silicone de condensação e adição a moldes em Próteses Fixas. Nesta revisão de literatura, foi realizado um levantamento dos dados PubMed, Scielo e Lilacs, utilizando os descritores: Prótese Parcial Fixa, Materiais para Moldagem Odontológica e Elastômeros. É possível concluir que os elastômeros, entre eles os silicones polimerizados por condensação e por adição, fornecem modelos de alta precisão e são os materiais mais utilizados em trabalhos com próteses parciais fixas. Portanto, cabe ao profissional conhecer as propriedades e se adequar ao melhor conjunto de materiais escolhidos.

Descritores: Prótese Parcial Fixa; Materiais para Moldagem Odontológica; Elastômeros.

\section{Resumen}

El moldeado en una prótesis fija es una de las etapas más importantes del tratamiento de rehabilitación, ya que es allí donde se intenta reproducir preparaciones dentales y regiones adyacentes utilizando materiales y técnicas adecuadas. Entre los materiales para moldear prótesis fijas disponibles en el mercado, destacamos los elastómeros, que son polímeros donde se produce el fraguado aumentando la corriente y estableciendo reticulaciones. El objetivo del estudio es presentar un caso clínico y realizar una revisión de la literatura sobre el uso de silicona de condensación y adición a moldes en Prótesis Fijas. En esta revisión de la literatura, se realizó una encuesta de datos de PubMed, Scielo y Lilacs, utilizando los descriptores: Dentadura Parcial Fija; Materiales de Impresión Dental y Elastómeros. Es posible concluir que los elastómeros, incluidas las siliconas polimerizadas por condensación y adición, proporcionan modelos de alta precisión y son los materiales más utilizados en el trabajo con prótesis parciales fijas. Por tanto, le corresponde al profesional conocer las propiedades y adaptarse al mejor conjunto de materiales elegidos.

Descriptores: Dentadura Parcial Fija; Materiales de Impresión Dental; Elastómeros.

\section{Molding in Fixed Partial Prosthesis is one} of the most important stages in rehabilitation treatment, as it is there that we try to reproduce dental preparations and the surrounding regions almost faithfully using appropriate materials and techniques ${ }^{1}$.

For a good impression result, we must take into consideration the quality of the impression material, as this should allow for an excellent negative reproduction of the region to be rehabilitated. In addition to the quality of the material, the execution of a good molding technique must also be taken into account and the choice of the best technique depends on three important requirements: extension of the preparation within the gingival sulcus, sharpness of the cervical end and health of the gingival tissue ${ }^{1}$.

According Puni et al. $^{2}$ the fundamental characteristics of impression materials should be: the ability to reproduce details accurately, have enough elasticity to not suffer changes in their properties after removal of the oral cavity, have tear resistance and most importantly: Have dimensional stability.

Among the fixed prosthesis impression materials available on the market, the elastomers stand out, which are polymers where the setting takes place through the increase of the chain and the establishment of cross-links. 
And they are able to reproduce oral structures with high precision and level of detail ${ }^{3}$.

Elastomers can be classified according to the type of polymerization: Addition or condensation. Addition polymerization products do not produce by-products and in the markets are found in the form of addition silicones and polyester. Condensation elastomers, on the other hand, produce by-products and are found in the market in the form of condensation silicones (alcohol as a by-product) and mercaptans or polysulfides (water as a byproduct) ${ }^{4}$.

Therefore, in order to achieve a fixed prosthesis impression with quality, it is necessary for the dentistry professional to know the materials and to master the impression technique. In this way, the present work proposes to search data in the literature about the most used materials in molding in the fixed prosthesis, in order to raise discussions and conclusions on the subject.

\section{CLINICAL CASE}

Male patient, JMFP, 35 years old, sought care at the prosthesis postgraduate clinic, complaining about the aesthetic appearance of his anterior teeth. In the first consultation, during the anamnesis, the patient reported that he had this space between his teeth since he was a teenager only that this condition has been leaving him dissatisfied for some years. On clinical examination the presence of diastema between upper central incisors was observed, due to the change in the size of the central and lateral incisors. (Figure 1).

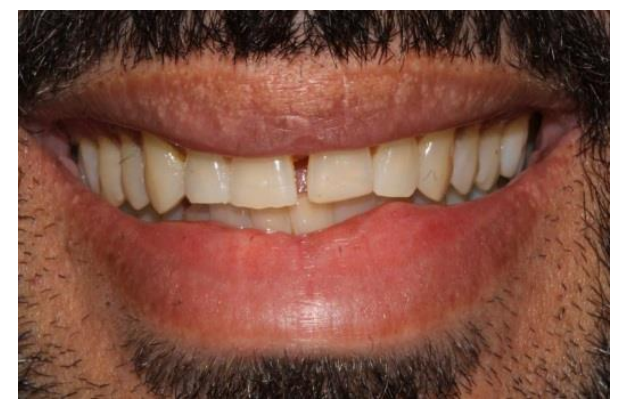

Figure 1: Diastema between upper central incisors.

On clinical and radiographic exams, it was found that elements 15 to 25 were vital, and without pulp involvement. For the clinical protocol, initially, an initial impression was made in the upper arch with addition silicone Presidente ${ }^{\circledR}$ (Coltene, Brazil), with the simultaneous double wire technique (Figure 2). Afterwards, a simultaneous single wire molding with Virtual@ (Ivoclair Vivadent, Brazil) was performed (Figure 3) for to obtain the plaster model. Then, the model was cut to form matrices (Figure 4) that allowed them to maintain the vertical and horizontal relationships of the teeth, as well as the contacts with neighboring teeth, aiming at the planning of disilicate laminate. Then, a milled CAD-CAM and a cut back make-up were used (Figure 5). And finally, disilicate laminates were made and implanted in the patient's teeth (Figure 6).

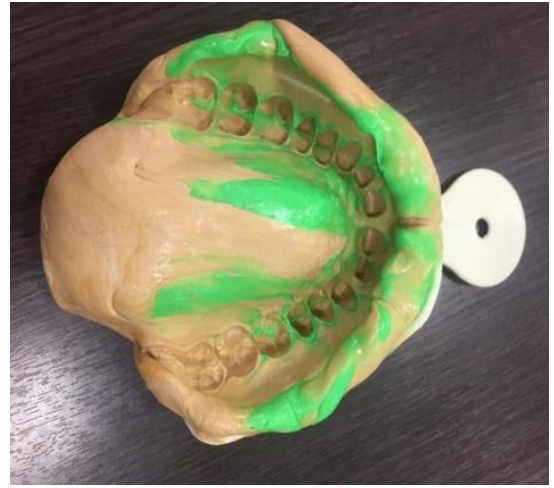

Figure 2: Initial impression with addition silicone Presidente $\AA$ (Coltene, Brazil), with the simultaneous double wire technique.

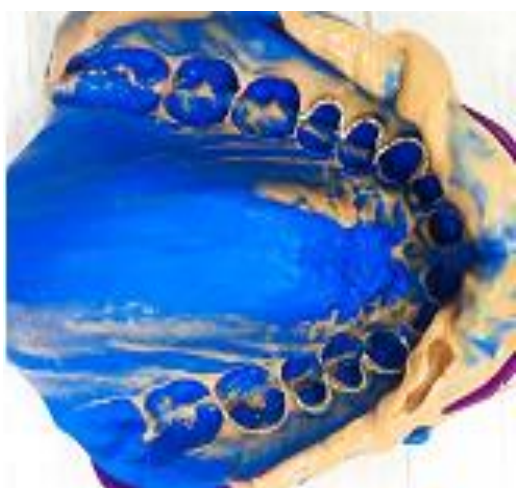

Figure 3: Simultaneous single wire molding with Virtual® (Ivoclair Vivadent, Brazil

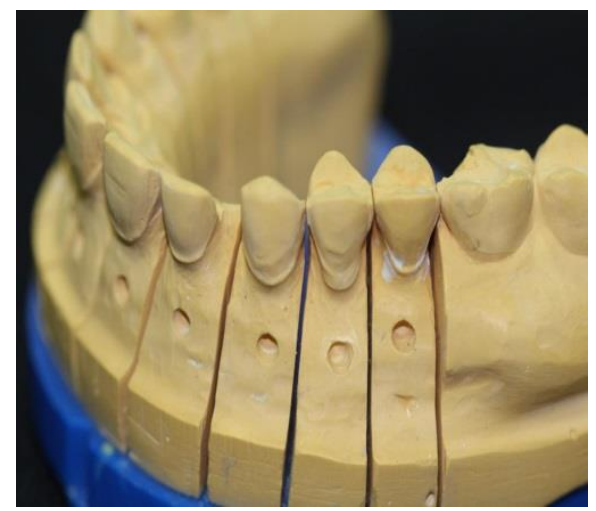

Figure 4: Model cutted to form matrices.

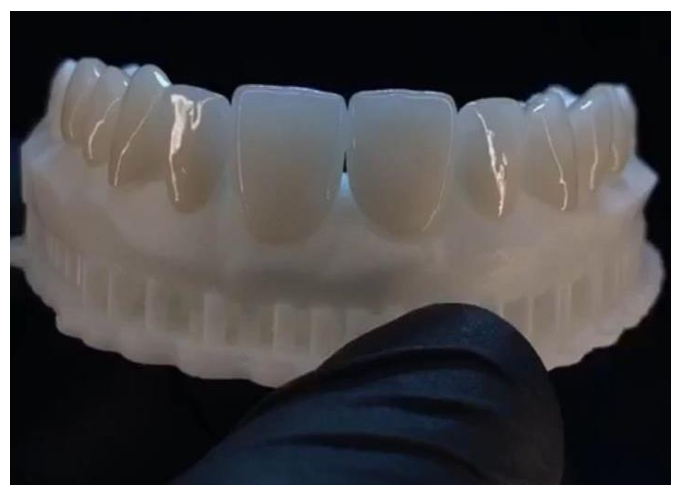

Figure 5: Milled CAD-CAM and a cut back make-up 


\section{LITERATURE REVIEW}

When planning a prosthetic rehabilitation work, the professional must select the technique to be used and the impression material according to the patient's clinical characteristics and the properties that will be necessary to obtain a good impression. Among them are the flow capacity, stability and reproduction fidelity. Over the years, a wide variety of molding materials and associated techniques have been developed and they are all seeking greater fidelity in reproducing details, reducing working time and providing more comfort to patients and professionals ${ }^{5}$.

Factors such as impression type, contraction of the impression material, permanent deformation, and storage stability and impression technique influence the ability to print or reproduce details and dimensional stability ${ }^{5}$. The impression has a very important value, because through it we obtain a direct link between the patient's mouth and the laboratory where a faithful copy of the oral structures will be obtained.

According Bustamante cites three basic requirements that must be observed for a good impression: the extension of the preparation, cervical end and provisional crowns. The prosthetic rehabilitator must respect all these requirements so that the prosthetic restorations respect biological, mechanical and aesthetic principles. The material must reproduce the soft and hard tissues around prepared teeth and adjacent teeth to obtain restorations/ prostheses with ideal characteristics.

The dimensional stability of impression materials is a characteristic of fundamental clinical interest. Among the materials on the market, silicones are the most used, due to the simplicity of their technique and the excellent results they provide ${ }^{7}$.

There are a number of factors that can affect the dimensional stability of silicones: conservation before use, proportionally correct material, handling, time and storage location of the mold. Once these factors are observed, we can obtain satisfactory results ${ }^{8}$.

According Franco et al. ${ }^{9}$, the volume of the impression material, the time it remains in the mouth, its modulus of elasticity, the temperature during the impression, the humidity during storage, the time between the removal of the impression and the leakage of the model are factors that can promote dimensional changes in the material.

There are several classifications of molding materials. Depending on how their components react to become solid, they can be called reversible or irreversible. In the setting reaction of irreversible materials, chemical reactions occur and prevent the material from reverting to its state before setting. When classified by their mechanical properties, the materials can be called elastic or anelastic/rigid. Among the elastic materials, there is a subdivision, in reversible/irreversible hydrocolloids and elastomers most used for molding today: the condensation and addition silicones ${ }^{5,10,11}$.

Reversible hydrocolloids are an elastic and flexible material based on agar, sufficiently capable of reproducing retentive areas, but they become less precise with storage, as the molds must be poured immediately after molding. The material must be removed immediately after the setting period because it tears very easily and has no adhesion to the stock tray. Already the irreversible alginate-based hydrocolloids, has a reproduction quality considered good and also a low cost in comparison to other types of molding materials. They are susceptibles to syneresis and imbibition, which causes their low dimensional stability. Moldings with alginate should be poured within 10 minutes after removal of the patient's oral cavity, however molds soaked with a wet gauze can wait for a longer time until the time of leakage, with clinically acceptable changes ${ }^{1,5,10}$.

Condensation silicones $^{6}$, also called polydimethylsiloxane ${ }^{12,13}$ appeared around 1950. Condensation silicones fulfill $68 \%$ of the requirements for an ideal elastic molding material. Its ability to reproduce fine details, simple and quick preparation, pleasant smell and tactile comfort for the patient position it as one of the most suitable materials for the manufacture of impressions in the dentistry. Its commercial presentation consists of a heavy dense mass, a light fluid paste and a catalyst paste for both light and heavy paste. The condensation silicone is so called because its type of polymerization reaction. According Hamalian et al. ${ }^{14}$ there may be a contraction with consequent dimensional change due to the slow polymerization of the condensation silicone. Polymerization is accompanied by the release of the by-product ethyl alcohol, which is greater in light consistency than in heavy ${ }^{15}$; therefore, we have a volatile product that can affect the dimensional stability of the mold ${ }^{12,13}$.

In moldings with condensation silicone, relief is achieved when firstly, a denser material with reduced reproducibility is used, followed by a new molding with a lighter material, promoting a much more accurate result ${ }^{16}$.

The evaporation of these by-products 
causes contraction of the condensation silicone; therefore, it is not recommended to leak the mold more than once, as this contraction extends over time. If condensation silicone molds not poured immediately they will result in a rapid loss of accuracy. Immediate leakage of the material is necessary, as dimensional changes increase the longer the storage time ${ }^{5}$.

Addition silicones have high dimensional stability as their main characteristic.They are available commercially in extra light, light, medium, heavy and very heavy consistencies. Addition silicones are the most stable molding materials, as no volatile by-products are released. This stability means that the mold does not need to be poured immediately ${ }^{17,18}$, and you can store the mold for one to two weeks to leak, depending on the trademark. In the setting reaction of the addition silicone, there is only the release of hydrogen gas from the mass of the material due to a secondary reaction between moisture and the residual hydrides of the base polymer; however, there is no distortion of the impression material after its release ${ }^{13}$. Releasing hydrogen gas as a by-product of the reaction does not affect dimensional stability but alters the surface quality of the cast.

Observing the manufacturer's indication of the waiting time required to empty the mold until all hydrogen gas has been released is very important. In addition Mezzomo e Suzuki ${ }^{19}$ state that it is hydrophilic, which allows good moldings at the gingival level and that, after polymerization, it becomes resistant to liquid sorption and can be easily disinfected in disinfectant liquids.

In relation to properties, the silicones by addition present moderate resistance to breakage and working time, rapid elastic recovery, without smell or taste, and can be poured up to one week after the mold is made, being stable in disinfectant solutions and commercially available in automatic dispensers. However, they are hydrophobic, difficult to pour, relatively expensive, poor adhesions to the trays, polymerization inhibited by the sulfur of the gloves and by the iron and aluminum sulphates, having a short validity ${ }^{15}$.

Molding is one of the main steps during the manufacture of Partial Fixed Prostheses and in order to have an excellent result in this step, it is important that the dentist has knowledge about the techniques that can be used and the most suitable materials. The techniques used are one-time molding technique, interdental relief technique, technique involving individual self-curing acrylic resin cap and technique with barrier (PVC or rubber sheet).
The technique which the dense and light paste shape the patient's arch present the advantage material savings in addition to clinical time. As a disadvantage, the presence of a second person is essential to assist in handling light and heavy folders at least ${ }^{20}$. Technique in which the heavy paste is first inserted with the tray into the arch, then interdental relief is performed to accommodate the light paste and then a second impression is made ${ }^{21}$. It presents as a major disadvantage a high clinical time and it has the advantage that the layer of the impression material is smaller than more homogeneous ${ }^{3}$. Technique that uses a barrier as a material interposed in the preparations performed, thereby providing a space for the slurry to occupy, right after the polymerization of the dense slurry ${ }^{2}$.

Therefore, in order to achieve a certain excellence in molding, it is necessary for the dentist to be familiar with some of these techniques, as well as the properties of the materials that he wishes to use for this ${ }^{11}$.

DISCUSSION

The molding is the most important and indispensable step for making dental prostheses ${ }^{11}$. The choice of the impression material and the best technique are essential steps for a correct and satisfactory impression. The main objective is to obtain a model that represents dental preparations and adjacent regions using appropriate materials and techniques. Among the materials available on the market for molding are elastomers. Elastomers are non-aqueous materials, as they are silicone polymerized by addition and silicone polymerized by condensation, polyester and polysulfides.

Polyester was the first elastomer developed with the function of molding oral structures, but its working time and setting time are short and cannot be used in more extensive rehabilitation. It is a hydrophilic material, confirming its use in humid environments, and the latest materials on the market are more flexible when compared to older materials. This facilitates the removal of the mouth ${ }^{3}$.

Polysulfides were originally a material produced to overcome deficiencies in hydrocolloids. The by-product generated in its reaction is water, which greatly affects its dimensional stability. It is one of the most rigid elastic materials and its disadvantages are the unpleasant odor and taste and the high setting time ${ }^{18}$. The use of these elastomers in the face of aesthetic and extensive rehabilitation treatments are falling out of use, because their 
disadvantages such as short handling and setting time and low dimensional stability, are going against what is expected in the results ${ }^{15,20}$.

Therefore, condensation and addition silicones are the materials used on a large scale in the performance of works in Fixed Partial Prosthesis and it is the choice of the professional on which material is best suited, always observing the inherent properties in each material so that it has a good impression and consequently a good result at the end of the treatment ${ }^{11}$.

Condensation silicone requires a very controlled technique, because it presents a major disadvantage, which is the formation of ethyl alcohol as a by-product, during the polymerization reaction. And by releasing this by-product it causes a volumetric contraction, thus leaving this material with low dimensional stability. Addition silicones, on the other hand, reproduce faithful molds and have the advantage of not forming a by-product, thus being able to leak the model within two weeks after molding ${ }^{16}$.

Lelis $^{13}$ analyzed the elastic recovery of silicones and said that the addition silicones have greater elastic recovery, that is, the capacity of the molding material to return to its original shape after removal, when compared to the elastic recovery of silicones of condensation. Only after elastic recovery can the models are subjected to leakage. The addition silicone lasts one hour and the condensation silicone lasts twenty minutes.

Marcinak et al. ${ }^{15}$ report in their study that the handling of silicones must be different with respect to the use or not of gloves. It reports that the addition silicones cannot be manipulated with the use of latex gloves by the operator, as it contains sulfur in its composition, which inhibits the polymerization reaction of the material. Rodrigues Filho et al. $^{22}$ point the handling of vinyl polysiloxane (addition silicone) impression putties with latex gloves is said to interfere with the setting of these impression materials.

\section{CONCLUSION}

It is concluded that: a) an accurate and stable material is essential for the success of the rehabilitation; b) there is a large number of materials and techniques that the professional must pay attention to and seek to know better to perform a good impression; c) addition-cured silicones are the most accurate and stable molding materials; d) the condensation silicones, when compared to the addition ones, have a lower performance (dimensional stability), but still guarantee molds with a lot of quality.

\section{REFERENCES}

1. Anusauice K, Phillips - Dental Materials. 11. ed Rio de Janeiro: Elsevier; 2010.

2. Punj A, Bompolaki D, Garaicoa J. Dental Impression Materials and Techniques. Dent Clin North Am. 2017;61(4):779-96.

3. Chen SY, Liang WM, Chen FN. Factors affecting the accuracy of elastometric impression materials. J Dent. 2004;32(8):603-9.

4. Antunes RPA, Matsumoto W, Panzeri $H$. Avaliação da capacidade de cópia de materiais de moldagem elastoméricos de diferentes sistemas por meio de uma técnica aplicável clinicamente. Rev Odontol Univ São Paulo. 1997;11(4):263:71.

5. Alves MC, Soares CR, Zani IM. Estabilidade dimensional dos moldes de poliéter tipo IV e V. Rev Odonto Ciênc. 2005;20(48):120-25.

6. Fano V, Gennari PU, Ortalli I. Dimensional stability of silicone-based impression materials. Dent Mater. 1992;8(2):105-9.

7. Craig RG, Powers JM, Wataha JC. Dental Materials - Properties and Handling. 7.ed. São Paulo: Santos; 2002.

Dias SC, Ávila GB, Panzeri H, Moisés MR, Ribeiro JCR, Ribeiro JGR et al. Analysis of the ability to reproduce details expressed by different modeling materials. Arq Odontol. 2007;43(4):137-43.

8. Franco EB, da Cunha LF, Benetti AR. Effect of storage period on the accuracy of elastomeric impressions. J Appl Oral Sci. 2007;15(3):195-8.

9. Idris B, Houston F, Claffey N. Comparison of the dimensional accuracy of one- and two-step techniques with the use of putty/wash addition silicone impression materials. J Prosthet Dent. 1995;74(5):535-41.

10. Noort RV. Introdução aos materiais dentários. Rio de Janeiro: Elsevier; 2010.

11. Higashi C, Gomes JC, Kina S, Andrade OS, Hirata R. Odontologia Estética - Planejamento E Técnica. Capitulo: 7 Planejamento estético em dentes anteriores; 2006.

12. Johnson GH, Craig RG. Accuracy of four types of rubber impression materials compared with time of pour and a repeat pour of models. $J$ Prosthet Dent. 1985;53(4):484-90.

13. Hamalian TA, Nasr E, Chidiac JJ. Impression materials in fixed prosthodontics: influence of choice on clinical procedure. J Prosthodont. $2011 ; 20(2): 153-60$

14. Lelis V. Bisacrílicas: características das restaurações temporárias [monografia]. Piracicaba: Faculdade de Odontologia. UNICAMP; 2014.

15. Marcinak CF, Young FA, Draughn RA, Flemming WR. Linear dimensional changes in elastic impression materials. J Dent Res. 1980;59(7):1152-5. 
16. Martins JT. Análise da precisão e reprodutibilidade de um scanner intraoral estudo clínico [dissertação). Almada: Instituto Superior de Ciências da Saúde Egas Moniz, Almada; 2014.

17.Pegoraro LF. Prótese Fixa. São Paulo: Artes Médicas; 2013.

18. Mesquita VT, Rodrigues RA, Dias AM, Machado CA, Batista AUD. Materiais e técnicas de moldagem em prótese fixa- revisão de literatura. Saber Científico. 2012;2(1):45-54.

19. Mezzomo E, Suzuki RM. Reabilitação Oral Contemporânea. Sao Paulo: Santos;2006.

20. Nissan J, Laufer BZ, Brosh T, Assif D. Accuracy of three polyvinyl siloxane putty-wash impression techniques. J Prosthet Dent. 2000; 83(2):161-65.

21. O'brien WJ. Materiais Dentários. Rio de Janeiro: Interamerican; 1981.

22. Rodrigues Filho LE, Muench A, Francci C, Luebke AK, Traina AA. The influence of handling on the elasticity of addition silicone putties. Pesqui Odontol Bras. 2003;17(3):25460.

\section{CONFLICTS OF INTERESTS}

The authors declare no conflicts of interests.

CORRESPONDING AUTHOR

Vandre Mesquita Taumaturgo

Coordenador de Pós-Graduação em Prótese Dentária POSDOC-PI,

64048-110 Teresina - PI, Brasil

E-mail: vtaumaturgo@yahoo.com.br 